\title{
Putting Qumran, Jesus and his movement into relief
}

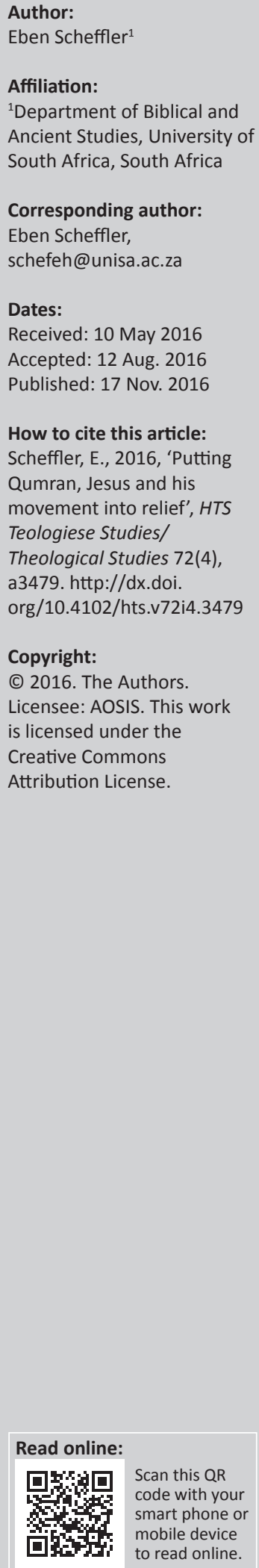

After referring briefly to the fantasies regarding the origins of Christianity as elicited by the discovery of the Dead Sea Scrolls in 1947 (Dupont-Sommer, Allegro, Thiering), the purpose of the contribution is to put the Jesus movement into relief in the context of first-century Judaism. The identity of the Qumranites is argued to be Essene scribes. The identity, ideology and practices of the latter are compared with those of Jesus of Nazareth and the movement he elicited using the following rubrics: (1) Jesus, the teacher of righteousness and the powers that be; (2) asceticism versus itinerary charismaticism; (3) caring versus lack of caring for the sick, poor and marginalised; (4) elitist priests and scribes versus lower-class peasants; (5) the interpretation of the law; (6) religious and daily practices (baptism, ritual meal, sacrifice, prayer, community of possessions, scribal activity); (7) religious views or ideology (kingdom of God, the new covenant, light and darkness, politics). The result is a picture of Jesus (with his focus on human suffering) in sharp relief versus Qumran and facets of the early church.

\section{Introduction}

I intentionally chose not to title this article 'Qumran and Jesus' (cf. Flint 2006, 2014; Horsley 2006; Stauffer 1959:13-16) but instead 'Qumran, Jesus and his movement', to include the beliefs and practices of the earliest followers of Jesus or the Urgemeinde (Conzelmann 1978:30-42; Reicke 1957). One may ask why such a reflection is necessary. The purpose is twofold, firstly to counter fantasies regarding the Jesus movement and Qumran that seem to recur constantly, even today, and secondly to get a better relief of Jesus and the movement he elicited within the context of firstcentury Judaism. In order to make such a comparison, one should have an operational point of departure $^{1}$ about the identity of the Qumranites and their relation to the scrolls. After spelling out my position in this regard, I compare the Qumran community and the Jesus movement under several rubrics, followed by some statements in conclusion.

\section{Speculations regarding Qumran, Jesus and the early church}

When the first seven scrolls were discovered in 1947 in Cave 1 by Mohammed ed-Dhib (De Vaux 1973), many popular speculations followed regarding their relationship with early Christianity. Some of these speculations were interpreted as a threat to Christian beliefs as such, and the fact that there had been an interruption in the publication of the scrolls (which in fact had more to do with personal problems than anything else) was interpreted by many as an embargo put on the publication by the Roman Catholic Church for fear of its faith being undermined. I will not give attention to the more popular publications now, except for two that came from 'scholarly circles' and one popular one of recent years. ${ }^{2}$

Within five years of the discovery of the scrolls, the French New Testament scholar Andre DupontSommer associated the Qumran community with the Jesus movement, by referring to resemblances he distinguished on the basis of studying some literature (the first discovered scrolls). In 1952 he argued that Jesus was an 'astonishing reincarnation' of the Hebrew 'Teacher of Righteousness' (or what he labelled the 'Master of Justice'):

Everything in the Jewish New Covenant heralds and prepares the way for the Christian New Covenant. The Galilean Master, as He is presented in the writings of the New Testament, appears in many respects as an astonishing reincarnation of the Master of Justice [the Teacher of Righteousness]. Like the latter $\mathrm{He}$ preached penitence, poverty, humility, love of one's neighbour, chastity. Like him, He prescribed the

1.'Operational point of departure' implies certain propositions that should be well-argued but need not be totally verified, in terms of which the research is undertaken. Arguments that follow may strengthen the point of departure or weaken it. In case of the latter, the relevant data should be reassessed.

2.Those who are interested in the popular furore are referred to numerous websites (cf. also Vermes 1977:24). 
observance of the Law of Moses, the whole Law, but the Law finished and perfected, thanks to His own revelations. Like him He was the Elect and the Messiah of God, the Messiah redeemer of the world. Like him He was the object of the hostility of the priests, the party of the Sadducees. Like him He was condemned and put to death. Like him He pronounced judgment on Jerusalem, which was taken and destroyed by the Romans for having put Him to death. Like him, at the end of time He will be the supreme judge. (Dupont-Sommer 1952:99; Flint 2006)

The second publication that caused a sensation is that of John Allegro, whose work elicited all the more attention since he was one of the official editors of the publication of the scrolls (see Allegro 1968). In his book The Sacred Mushroom and the Cross (1970; cf. also 1979), he asserted that there grew a specific mushroom at Qumran, which once ingested caused the Qumranites to experience delusions resulting in religious fantasies, of which the whole Jesus story was the result. Allegro therefore became one of the most prominent Jesus deniers or what are today called 'mythicists'. Allegro's book suggested that the discoveries at Qumran (excavations as well as scrolls) revealed that Jesus did not exist and that Christianity is a scam. Today fantasies like that of Allegro still appeal to some would-be sceptics (discussion in cf. Ehrman 2012). It is also understandable that Christians supposing Allegro to be right were shocked in their faith.

However, Flint (2006:111) is correct in stating that the resemblances that Dupont-Sommer detected do not represent real connections between Qumran and early Christianity. Dupont-Sommer indeed put points of comparison on the table (he compared but did not identify Jesus as the Master of Justice), but as discussed below a close scrutiny of these points of comparison reveal differences of cardinal importance.

In 1992 Barbara Thiering of the University of Sydney published her book Jesus the Man, which is described on the title page as 'the controversial bestseller that will change forever your view of Christianity'. According to her Jesus was the 'Wicked Priest' of Qumran, opposing the 'Teacher of Righteousness', who in her view was John the Baptist. Jesus led a radical faction of Essene priests, was not born of a virgin, did not die on the cross, was married to Mary Magdalene, fathered a family and later divorced. He died after AD 64 (Thiering 1992). What to Kazantzakis was a 'temptation' in his novel The Last Temptation of Christ, ${ }^{3}$ for Thiering became real history. According to her the Gospels were encoded to be read with the Qumran pesher method ${ }^{4}$ of exegesis, an assumption that obviously enables one to prove anything from a text (like in allegorical exegesis). Her views can easily be dismissed on scholarly grounds (cf. Flint 2014:269-271). What is disturbing is the fact that the sensation of her work caused it to be widely disseminated, with the result that it remains the task of more honest (and economically deprived!) scholars to be the spoilsports and see to the dilution of her fantasies.

3.A highly successful film (with the same title) based on the book was produced in 1989.

4.For a discussion of the method, see Barret (1970:386-389).
However, I, for my part, am of the opinion that honest comparison between the Qumranites and the Jesus movement also provides many interesting insights.

\section{The Qumranites as Essene scribes}

Important for the relationship between Jesus and his movement and Qumran is the simple question of who lived at Qumran, in other words the identity of the Qumranites. If one follows the methodology to relate the Serek Hayachad (Community Rule, 1QS) and Damascus Rule (CD) to the excavations done by De Vaux and his team (De Vaux 1973; De Vaux \& Broshi 1993:1235-1241; Scheffler 2000:185-188), which most scholars do, to my mind the question can, to a great extent, be answered. A comparison between 1QS, CD and Pliny and Josephus on the Essenes renders enough similarities to conclude that the Qumranites were part of the broader Essene movement. For the sake of comparison I quote the relevant texts from Pliny (see Table 1) and Josephus (Table 2). ${ }^{5}$

The most widely accepted assessment on the identity of the Qumranites is thus that they were an ascetic Essene sect (Albright 1960:222-223; Baumbach 1969:226; Bimson \& Kane 1985:59; Bornkamm [1956] 1975:39-40; Botha 2001:67-76; Bruce 1974:169-175; Burrows 1961:740; Casey 2010:121-123; Crossan \& Reed 2001:7; Davies 1989:340-342; Du Randt 1998; Eshel 2009:26-27; Farrington 2003:114; Flint 2013:127-152; Gal 2010:18-19; Gunneweg 1972:161; Hengel 1988:394; Hermann 1980:473; Jagersma 1985:102-110; Keller 1981:423-4316; Kravitz 1973; Meeks 1986:75-81; Metzger 1983; Millard 1990:102-114; Murphy O'Connor 2008:46; Noth 1960; Pfeiffer 1957:85; Reicke 1968:125-126; Ringgren 1963:314-315; Schonfield 1984; Stauffer 1959; Stegemann 1998; Tenney 1967:95-106; Thompson 1989:269-287; Van der Ploeg 1957:68; VanderKam 2010:127-156; Vermes 1977:125-130, 1998:46-48; Vriezen \& Van der Woude 1973:367-369; Wright 1962:216-220, 235-238). However, this conclusion, based on the quoted texts, is not without problems and refinement of the thesis is needed (see discussion in Fensham 1976:25-35; Golb 1995:1157; Maier 1972:57-63; VanderKam 2010:97-126). Pliny the Elder (who took part in the siege of Jerusalem in $70 \mathrm{CE}$ and learned a great deal about Palestine) gives much geographical information in his Natural History that seems to coincide with Khirbet Qumran. For only one place corresponds with the geographical location that Pliny gives for the Essenes, namely Qumran and the Ain Feschka community. In Wadi Murabbat (to the south of Qumran) there were also a few caves with traces of human settlement, including a few texts, but not to the extent that one can speak of a community.

5.Further ancient texts dealing with the Essenes are: Josephus's Bell.Jud. 2122 and Philo Quod omnis probus liber sit, Par. 12.

6.In spite of the fact that Keller's book reveals (as the title suggests) a fundamentalist bias, the section on the Dead Sea Scrolls makes for vivid reading.

7.Golb's hypothesis that the site was a military fortress and should not be linked to the scrolls at all has not found significant support. For an informative discussion of the Essenes before the 1947 scrolls were discovered see Oesterley (1932:323-328). 
TABLE 1: Pliny the Elder on the Essenes.

Ab occidente litora Esseni fugiunt usque qua nocent, gens sola et in toto orbe praeter ceteras mira, sine ulla femina, omni venere abdicata, sine pecunia, socia palmarum. in diem ex aequo convenarum turba renascitur, large frequentantibus quos vita fessos ad mores eorum fortuna fluctibus agit. ita per saeculorum milia - incredibile dictu - gens aeterna est, in qua nemo nascitur. tam fecunda illis aliorum vitae paenitentia est! infra hos Engada oppidum fuit, secundum ab Hierosolymis fertilitate palmettorumque nemoribus, nunc alterum bustum. inde Masada castellum in rupe, et ipsum haut procul Asphaltite.

On its west side [of the Dead Sea - EHS], just far enough from the shore to avoid its baneful influences, live the Essenes. They form a solitary community, and they inspire our admiration more than any other community in the whole world. They live without women (for they have renounced all sexual life), they live without money, and without any company save that of the palm trees. From day to day their numbers are maintained by the stream of people that seek them out and join them from far and wide. These people are driven to adopt the Essenes' way of life through weariness of ordinary life and by reasons of the changes of fortune. Thus, through thousands of generations - incredible to relate - this community into which no one is ever born continues without dying; other people's weariness of life is the secret of their abiding fertility! Below their headquarters was the town of En-gedi, whose fertility and palm-groves formerly made it second only to Jerusalem; but now, like Jerusalem itself, a heap of ashes. Next comes Masada, a fortress on a rock, itself not far from the Dead Sea.

Source: www.thelatinlibrary.com/pliny.nh5.html\#73

TABLE 2: Josephus on the Essenes.

\section{Antiquitates 18:18 (Greek)}

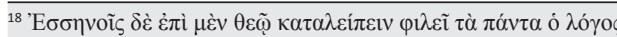

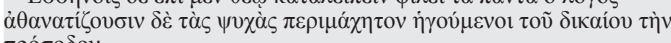
$\pi \rho \sigma_{\sigma o \delta} \mathrm{ov}$

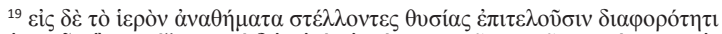

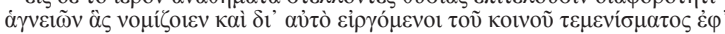

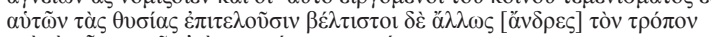

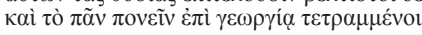

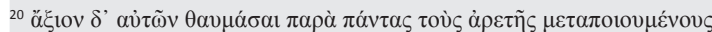

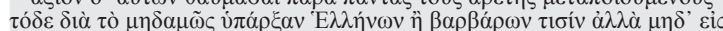

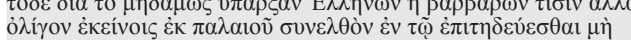

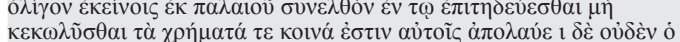

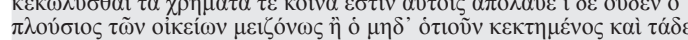

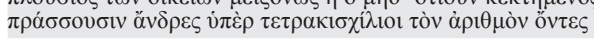

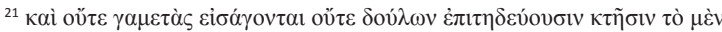

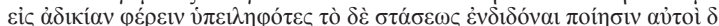

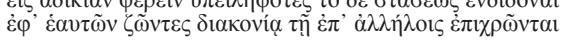

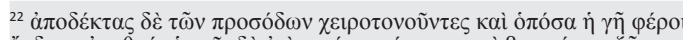

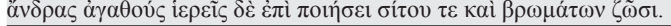

\section{Antiquitates 18:18 (English)}

${ }^{18}$ The doctrine of the Essenes is this: - That all things are best ascribed to God. They teach the immortality of souls, and esteem that the rewards of righteousness are to be earnestly striven for;

${ }^{19}$ and when they send what they have dedicated to God into the temple, they do not offer sacrifices, because they have more pure lustrations of their own; on which account they are excluded from the common court of the temple, but offer their sacrifices themselves; yet is their course of life better than that of other men; and they entirely give themselves over to husbandry.

${ }^{20}$ It also deserves our admiration, how much they exceed all other men that give themselves over to virtue, and this in righteousness: and indeed to such a degree, that as it has never appeared among any other men, neither Greeks nor barbarians, no, not for a little time, so has it endured a long time among them. This is demonstrated by that institution of theirs, which will not allow anything to hinder them from having all things in common; so that a rich man enjoys no more of his own wealth hinder them from having all things in common; so that a rich man enjoys no more of his own
than he who has nothing at all. There are about four thousand men that live in this way,

${ }^{21}$ and neither marry wives, nor are desirous to keep servants; as thinking the latter tempts men to be unjust, and the former gives the handle to domestic quarrels; but as they live by themselves, they minister one to another.

${ }^{22}$ They also appoint certain stewards to receive the incomes of their revenues, and of the fruits of the ground; such as are good men and priests, who are to get their grain and their food ready for them.

Source: Text from BibleWorks for Windows

Besides the geographical description, the Pliny text mentions two features of the Essenes that match the description of the community described in 1QS. These two features are the absence of women and the denunciation of wealth. However, the archaeological record problmatised this.

As far as women are concerned (cf. Pliny's sine ulla femina [without women]) excavations of the cemeteries to the east, north and south of the ruins revealed that women and children (about $10 \%$ of about 1000 graves) also stayed at Qumran (De Vaux \& Broshi 1993). To maintain Pliny's 'celibate' thesis, one therefore has to conclude that the women were not married to full members (as stated by Josephus ov̋ $\tau \varepsilon$

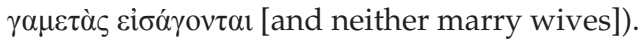

As far as money is concerned (cf. Pliny's sine pecunia [without money]), the coins discovered by archaeologists should be interpreted as being commonly owned by the Qumranites

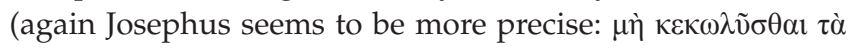

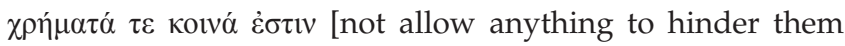
from having all things in common]).

According to Pliny's description, it seems as if only Essenes lived at Qumran. He should therefore again be complemented with Josephus's account. The latter, in his Judean Wars (2:8:213) and Antiquities of the Jews (18:18), gives more information on the Essenes' religion and he does not limit the Essenes specifically to the Dead Sea. One can therefore conclude that if the Qumranites were an Essene sect, it does not mean that they were the only ones in the country. The Qumranites were Essenes, but all Essenes were not Qumranites. Josephus estimates that there were about 4000 Essenes and we know from the archaeological records (death rates as revealed by the cemeteries) as well as the size of the complex that only about 50 people could have lived at Qumran at any stage (Bimson \& Kane 1985). Some more could have lived outside the complex.

However, can we define the Essenes even further in order to know what we want to compare with the early Jesus movement? The word 'Essene' derives from the Greek for 'pious', ${ }^{8}$ of which the equivalent Hebrew is hassid. The Hassidim are a well-known conservative Jewish group who emerged in the second century BCE. When the Syrian ruler of Palestine, Antiochus Epiphanes IV enforced a Hellenisation policy in Palestine in 168 BCE, he regarded the Jewish religion as a threat to the unity of his empire, sought to eradicate Jewish customs and defiled the temple in Jerusalem. The Jews resisted in what became known as the Maccabean revolt and regained their independence.

A split in Jewry now occurred. Some, under the leadership of Jonathan the high priest (Maccabean leader from 161 to 143 and appointed high priest by the Seleucid leader Alexander Balas), thought Hellenisation to be to the benefit of the Jews. On the other hand, the conservative Hassidim endeavoured to keep to the pure Mosaic tradition and the covenant. The leader of the Hassidim can then probably be identified with the Teacher of Righteousness of the scrolls, who opposed the Wicked Priest, possibly to be identified with Jonathan and his successors in Jerusalem. According to this theory, the Qumranites were part of the broader Essene or Hassidim 8.The Greek essaioi, in turn, derives from the Aramaic chaseh, plural chasen (Oesterley 1932:323). 
movement, who as a reaction against the Hellenisation process in Jerusalem withdrew to the desert. There they lived in Qumran (possibly the main centre) and vicinity (Ain Feska, Murrabat, Ein Gedi and Masada included) for nearly 100 years of Hellenistic rule and a further 100 of Roman rule, until the community was defeated during the Jewish war of $70 \mathrm{CE}$ and ceased to exist (Yadin 1973:203-231).

However, one question still needs to be answered. Why did they choose the desert? Those who have visited the ruins in summer when the temperature can rise to 45 degrees Celsius will ask this question with an exclamation mark.

Stegemann (1998) argues, convincingly to my mind, that the archaeological excavations indicated that the Essenes who settled in Qumran did not do so merely to flee from Jerusalem or to practise their order but especially to produce scrolls. There are several reasons for this. Firstly, the hot and dry climate, especially the climate in the caves, was conducive for the preservation of the scrolls, as 2000 years of preservation testify. Secondly, there was a scriptorium in the complex with tables and inkpots uncovered. Thirdly, the waters of the salty Dead Sea facilitated a better method of preparing the leather for the scrolls. The Qumran scrolls are made of sheepskin or goatskin, and these were the only animals that could live there.

Part and parcel of the Qumranites' identity was therefore that they were scribes (like those mentioned in the Gospels) who produced their scrolls, studied them and from there distributed them all over the country. As part of the pious Essene movement they also devoted a lot of time to study. Scrolls were obtained from the library - the latter was probably discovered in Cave 4. They lived according to the strict rules of the community in accordance to their identity as Essenes, Hassidim or scribes.

When the Romans occupied the site in $68 \mathrm{CE}$, the Qumranites were either killed or fled to Masada to join the Zealots, with whom they had much in common. It is possible that some joined the early Christians, who survived the Jewish war because of their non-violent stance. Before leaving, they succeeded in hiding their scrolls in nearby caves, where they remained for nearly 2000 years.

The New Testament writings reflect much about early Christianity (see Conzelmann 1978; Schnackenburg 1973; Theissen 2004) and, having obtained, through the archaeological record, a glimpse of the identity of the Qumranites as Essenic scribes, comparing the two promises to provide more insight into both.

Vermes to my mind correctly pointed out that there are three possibilities as to the relation between the Essenic scribes and the Jesus movement (1977). Firstly, there could have been overlap, meaning that the Qumranites were Christians; secondly the Christians could have sprung from the Essene movement; and thirdly they may have been totally separate.
As will become clear below, the third option still carries the day, although I surmise that there exists a high probability that after 68 CE the Qumranites (or a large portion of them) joined the Jesus movement and exerted a considerable influence in the early Christian church. This influence may be indicated in the New Testament writings, of which many were authored late in the first century.

At the outset it must be noted that neither Jesus (nor any other New Testament character) is mentioned in the scrolls, nor was any New Testament text or fragment thereof found at Qumran (despite the presence of the term 'New Testament', see Vermes 1998). ${ }^{9}$ Usually scholars of the scrolls compare the scrolls with the New Testament and find many similarities in vocabulary and ideas (e.g. Fensham 1976; Flint 2014:272282; VanderKam 2010:197-226; Vermes 1998:21-23). Very few, when making such comparisons, make a clear and sharp distinction between the historical Jesus and the movement he elicited or the early church, which as such is reflected in the New Testament. ${ }^{10}$ And this after Rudolph Bultmann made all New Testament scholars aware of Gemeindetheologie (1968:34-186). Ethelbert Stauffer, who wrote the book Jesus, damals und heute in 1959 before all the scrolls were discovered, is a notable exception. In what follows I scrutinise five selected themes (leadership, societal role, internal hierarchy, membership and ethos) in order to demonstrate the similarities but especially the clear differences between the Qumranites, the historical Jesus and the post-Easter church. This is followed by indicating further similarities and differences pertaining to religious practices and religioideological views.

\section{Social identity: Qumran, Jesus and the early Church \\ Jesus, the teacher of righteousness and the powers that be}

Having discarded the notion of Jesus of Nazareth and Qumran's Teacher of Righteousness being the same person, some noteworthy similarities and differences can nevertheless be distinguished (e.g. Horsley 2006:58-60). Both preached penitence, humility, love and justice. The Teacher of Righteousness demanded poverty as an (ascetic) ideal, whereas Jesus identified with the poor and acted on their behalf. For him (partial) renunciation of possessions (Lk. 12:33) had the aim of compassionate caring for the poor (Scheffler 1993:67-69; Schottroff \& Stegemann 1978:136-149). Ascetic chastity was important for the Teacher at Qumran, whereas amongst non-Qumranite Essenes marriage was not totally forbidden (comparable to Paul's view in 1 Cor 7). For Jesus celibacy was an option, but on a voluntary basis for the

9.Millard (1990:115) discussed the possibility of a papyrus fragment containing the text of Mark 6:53 and concluded: 'Although it is possible the identity is not proved. Even if some people of Qumran did read the Gospel, there is no sign of it affecting the teachings of the people living there.'

10. Of course the distinction between the views of the Jesus of history and the early church involves a complex process and will perhaps never have the claim of finality. As far as the criteria used, I subscribe to those usually used (analogy, dissimilarity, multiple attestation) but concur with Theissen and Merz (2011) with regard to the multiple attestation) but concur with Theissen and Merz (2011) with regard to the
criterion of plausibility. In the end constructions of Jesus have to be scrutinised in the public scholarly debate. 
sake of the kingdom (Mt 19:12), at the same time opposing divorce (Mk 10:1-12; 1 Cor 7:10) and having empathy for prostitutes and adulterers (Mt 21:31-32; Lk 7:36-50; Jn 8:5311,11 cf. Theissen \& Merz 2011:494). The Teacher's radical opposition to the Wicked Priest of Jerusalem can be compared to Jesus' opposition to the temple hierarchy as it found expression in the report of him 'cleansing the temple' (Mk 11:15-17; Mt 21:12-7; Lk 19:45-48; Jn 2:13-22). However, in Jesus' case, the opposition initially was less radical. He went as a pilgrim to the feasts in Jerusalem, taught there but then probably became disillusioned. After Easter the disciples gathered in the temple (Ac 2:46). As the early movement spread in the Hellenistic world, the Jerusalem temple became less important. Christians would gather in private houses and the temple became a metaphor for the human body, which calls to mind the Qumranic view that the community as a whole functioned as a temple. In the early church, what Stauffer (1959:8-11) would label the 'Judaising' or 'Qumranising' of the Jesus movement, hierarchies developed similar to those at Qumran which contrasted with Jesus' teaching of leadership as service (Mk 10:41-45). Vermes (himself a Jew, 1998) remarkably concluded:

Essenism is dead. The brittle structure of its stiff and exclusive brotherhood was unable to withstand the national catastrophe which struck Palestinian Judaism in 70 CE. Animated by the loftiest ideals and devoted to the observance of 'perfect holiness', it yet lacked the pliant strength and the elasticity of thought and depth of spiritual vision which enabled rabbinic Judaism to survive and flourish. And although the Teacher of Righteousness clearly sensed the deeper obligations implicit in the Mosaic Law, he was without the genius of Jesus the Jew who succeeded in uncovering the essence of religion as an existential relationship between man and man and man and God. (p. 25)

\section{Asceticism versus itinerary charismaticism}

The Qumranites withdrew from society whereas Jesus entered into it. It is consensus amongst scholars that the Qumranites constituted an ascetic movement with strict rules. The Teacher's opposition to the temple after Alexander Janneus became high priest (cf. above) caused the Essenes to withdraw to the desert to live a kind of ascetic life, fully devoting themselves to what they regarded as the true Mosaic religion. Their asceticism and strict lifestyle are clearly reflected in the Serek Hayachad (Community Rule, 1QS and $4 \mathrm{QSd}=4 \mathrm{Q} 258$ ), the so-called Rule of the Congregation (1QSa) and the Damaskus Document (CD, 4Q265-273). ${ }^{12}$

Theissen (2004:33-98) argued, to my mind correctly, that Jesus and his first followers were itinerant charismatics who did not withdraw from what Jesus would regard as evil in society but rather confronted it. Schnackenburg (1973:288-292) referred to Jesus' 'charismatic-prophetic

11.Although the comma Johanneum was only inserted later in the Johannine text, it nevertheless to my mind reflects the intentio Jesu.

12.Numerous translations have been made to date, of which Lohse (1971:4-107) (Hebrew with German parallels), Martínez and Tigchelaar (1999) (Hebrew with English parallels) and Vermes (1998:125-143, English) are to my mind the most English parallels) and Vermes (1998:125-143, English) are to my mind the most
useful. Unless otherwise stated in this article I quote from the translation of useful. Unless ministry', which included disciples not for studying the law (like a rabbi would) but who, gripped by his person and message, would minister among all Jews:

As a homeless itinerant preacher and healer he travelled on foot through Palestine and focussed on small villages at the northwestern end of the lake of Galilee. From simple people, from fishers and peasants, he chose twelve disciples with Peter as leader, representatives of the twelve tribes of Israel. (Theissen \& Merz 2011:493)

Jesus' main aim was not to combat a Wicked Priest, but poverty, sickness, psychological suffering, social ostracism and enmity among humans. This is clearly expressed in the summaries in the Gospels, stating that Jesus went to all the village towns healing and teaching. He was no ascetic, but a self-confessed 'eater and drinker', for which he was scolded as a 'glutton and drunkard', playing the flute for the children to dance in the marketplace (in contrary to John the Baptist, cf. Mt 11:16-19; Lk 7:31-24). However, when the Jesus movement became sedentary (after Easter) many beliefs and practices were adopted that resembled those of Qumran (see below).

\section{Elitism versus lower-class peasantry}

As far as membership is concerned there is a clear distinction between Qumran, the historical Jesus and the church after Easter. The Qumranites were elitist, considering themselves chosen ones and belonging to the Zadokite high priest nobility, the difference from the Jerusalem high priests being that they were against cooperation with Rome. To become a full member of the community took 3 years of initiation, and a pious lifestyle had to first be proven (1QS 5:1-3). In the community there was also a strict hierarchy as expressed in 1QS 5:20, 23-24 (cf. also 1QS2:19-24):

But when one enters the covenant ... they shall inscribe them in order, one after another, according to the understanding of their deeds, that everyone may obey his companion, the man of lesser rank obeying his superior. And they shall examine their spirit and deeds yearly, so that each man may be advanced in accordance with his understanding and perfection of way, or moved down in accordance with his distortions. (1QS 5:20, 23-24)

Any idea of rank amongst his followers was nipped in the bud by the historical Jesus, as can be seen from James and John's request in this regard (Mk 9:33-37; 10:35-45; Mt 20:3545; Lk 22:24-27) and his washing of his disciples' feet in John's Gospel (Jn 13:4-5,12-17). Stauffer (1959:13) expressed it appropriately: 'In the community of Jesus' followers, noble predicates and ancestral passports meant absolutely nothing ${ }^{\prime}{ }^{13}$ To the contrary, to the Jesus movement belonged what Crossan (1991:266-276, 1994:54-74) typified as 'nobodies': the poor, peasants, fisherman, illiterates, prostitutes, toll collectors and sinners: the scum of the earth. For Jesus the repentance of sinners was important (Mk 1:14-15), but it was preceded by their unconditional social acceptance (Mk 2:13-17; Lk 15:1-2, 20-24; Lk 19:1-10; cf. 13.The author's English translation of the following: 'In der Jüngergemeinde bedeuten Adelsprädikate und Ahnenpässe überhaupt nichts'. 
Scheffler 1993:99-102). This social acceptance on an existential level (expressed concretely in table fellowship) preceded conversion.

In Acts, Luke portrays the early church as continuing social acceptance and open table fellowship (Ac 2:43-47; 4:32-37). Although believers were popular among the common people, implying an open relationship with society, the voluntary 'open commensality' (Crossan 1994:66-70) became a feature of the believers themselves and their gatherings, apart from the people. Soon in the post-Easter church, as can be seen in (deutero-)Pauline literature and even the Gospels, moralistic virtue became a prerequisite (1 Cor 6:9-10; Gl 5:19-21; Eph 5:3-5; Mt 5:27-30; 18:15-16; 1 Th 2:12; Rv 16;10-11). And as more and more middle-class people joined the church (whom Luke addresses in his Gospel ${ }^{14}$ ) and doctrinal disputes increased, the poor were increasingly neglected (implied in Gal 2:10).

\section{Exclusivism versus care for the sick and the marginalised}

Despite the Community Rule quoting Psalm 146:7-9 (God caring for the oppressed, prisoners, the blind, the bowed down, strangers, widows and orphans), the Qumran community had the following stipulation regarding membership:

No man smitten in his flesh, or paralysed in his feet or hands, or lame, or blind, or deaf, or dumb, or smitten in his flesh with a visible blemish; no old and tottery man unable to stay still in the midst of the congregation; none of these shall come to hold office among the congregation of the men of renown ... (1QSa 2:4-8)

... no madman, or lunatic shall enter, no simpleton, or fool, no blind man, or maimed, or lame, or deaf man, and no minor, none of these shall enter the community... (CD 15:15; constructed from 4Q266, 8i:6-9)

Children and women were also mostly excluded. This constitutes a cardinal difference from Jesus, who devoted his whole life to serve the sick and the marginalised (e.g. women and children) directly (cf. e.g. Mk 1:32-34; 3:7-12; Lk 7:21-22). Although scholars who study the historical Jesus may have debated the miraculousness of his healings since the time of Strauss (1835, cf. also Schweitzer [1906] 2001:74-90; Theissen \& Merz 2011:260-264), all would agree that he acted as a compassionate (traditional) healer among his contemporaries (see Craffert 2008:213-308; Crossan 1994:75-101; Davies 1995; Scheffler 1993:87-90; Theissen \& Merz 2011:265-282). For Jesus, the gospel was good news because exactly these people were targeted. Women (e.g. Lk 8:1-3; 23:28, cf. Dreyer 1999:70-96) and especially children (Mk 10:13-16; Mt 19:13-15; Lk 18:15-17, cf. Crossan 1994:62-64) took a central place in his ministry. It is amazing that some scholars who compared the scrolls with the New Testament often would not pay attention to this important contrast between the Qumran community and the historical Jesus (e.g. Flint 2014; Horsley 2006; Pfeiffer 1957:44-46,85-87; Van der Ploeg 1957:165-194; VanderKam 2010:197-226; Vermes 1977:2011-2221). It is also significant that the post-Easter church, although not putting it in the same focus as Jesus, never lost their concern for the sick and handicapped (cf. the report on healings in Acts).

\section{Apodictic keeping of the law and surpassing freedom}

For the Qumranites, obedience to the stipulations of Mosaic Law was of the utmost importance and constituted the essence of their religion (see Harrington 2000). Keeping the law was a precondition for entrance into the community and a strict penal code was applied for even minor transgressions (1QS 6:25-7:25). According to 1QS 5:7-9 (cf. also 1QS 1:7-9; 5:21):

Whoever approaches the Council of the Community shall enter the Covenant of God in the presence of all who have freely pledged themselves. He shall undertake by a binding oath to return with all his heart and soul to every commandment of the Law of Moses in accordance with all that has been revealed of it to the sons of Zadok, the Priests, Keepers of the Covenant and Seekers of his will .... 1QS 5:7-9

Jesus was not against the law and Matthew 5:17-20 ('not a iota, not a dot, will pass away from the law until all is accomplished') may suggest that he was just as strict as the view expressed in the Community Rule. However, what 'accomplish' implies should be understood in terms of the antitheses that follow in the Matthean text (Mt 5:21-48), where the mere literal meaning of law stipulations is surpassed. Jesus emphasised those aspects of the law that enhance love, compassion and justice amongst human beings. For that reason, the sabbath was interpreted as being for the benefit of humans (Mk 2:28), some purity laws could be ignored (Mk 7:1-23) and the bringing of sacrifices relativised in view of the love commandment (Mk 12:33).

To keep the tradition as expressed in the Jewish scriptures was central to Qumranites - therefore they produced and studied the scrolls. The scribes counted as Jesus' opponents because salvation for him was not to be found in the study of the scriptures but in God's direct unconditional acceptance and forgiveness of sinners, and people accepting the kingdom like children (even faith being not so important, Lk 18:15-17). However, despite Paul's adage in 1 Corinthians 13:13 that love is greater than faith, in the post-Easter church, faith in certain tenets (for instance the sacrificial interpretation of Jesus' death, confessing him as kurios and Messiah, and baptism) became the criterion to become a member of the church. Jesus had freedom in his interpretation of scripture, with the love command as his criterion (the law and the prophets depending on it, Mt 22:14), whereas in the emerging Christianity the Jewish scriptures increasingly regained their absolute authority as inspired scripture (2 Tm 3:16).

\section{Religious practices and views}

Constraints of space do not allow us to explore the similarities and clear differences between the Qumranites, Jesus and the early church to the full. In what follows, differences are briefly indicated regarding religious practices and 
religio-ideological views, which to my mind corroborates the picture that has emerged thus far.

\section{Ritual washings and (no) baptism}

At Qumran ritual washings took place on a daily basis for purification (as several excavated ritual baths testify) but also on entrance into the community (proselyte baptism, cf. 1QS). Jesus of Nazareth was baptised by John the Baptist, but he himself was never baptised (Jn 4:1-2). Paul baptised only a few people and he used the concept of baptism as a metaphor to express the believers sharing in the death of Jesus. In the post-Easter church, baptism became standard practice (probably because of the movement of John the Baptist that merged with early Christianity) and was prescriptive after conversion, similar to the proselyte baptism of the Qumranites. The latter's daily baptisms were absent in the church. In comparison to Qumran, John the Baptist and the early church, Jesus refraining from baptising people was remarkably unique.

\section{Sharing of possessions}

After a trial period of about three years, on becoming a full member of the community, a novice would submit his wealth to the common treasury of the community, which would then look after his needs (1QS $1: 11-13 ; 7: 6-7 ; 6: 25)$. In this way poverty was eradicated amongst community members. ${ }^{15}$ This ruling remarkably resembles Luke's view of the earliest church directly after Easter (Ac 2:43-47; 4:32-36; cf. Reicke 1957:60), the difference being that in Qumran it was compulsory, whereas in Acts the first Christians were portrayed as having shared their possessions voluntarily. The historical Jesus probably was a carpenter (Mk 6:3) and his disciples fishermen (Mk 2), neither profession representing the poorest of the poor. During his itinerant ministry he was cared for by his female followers (Lk 8:1-3) and directed his

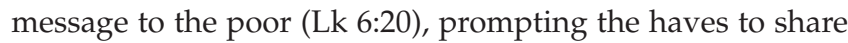
with the have-nots (Mk 10:21; Lk 12; 16:19-30, Gospel of Thomas 54, 69b, cf. Crossan 1994:154). Jesus did not establish congregations but urged his followers to enter society and preach the kingdom (which included healing of the sick and ministering to the poor; Lk 7:21-22). Despite Galations 2:10, where Paul committed himself to caring for the poor, the liberation of the poor was not his main focus. The Letter to the Romans reflected Paul's main interest as salvation through faith in Jesus as the Christ (Rom 1:17). The poor functioned as an 'afterthought' (cf. Gal 2:10) in Paul's project to collect money in the Asian churches to be sent to the poor in Jerusalem (cf. 2 Cor 8-9). A more positive attitude (reflecting more the stance of the historical Jesus) is to be found in the letter to James (chapter 2).

\section{Ritual meal, open commensality and the Eucharist}

In the refectory in the Qumran complex (excavated by De Vaux, cf. 1973; Scheffler 2000:197-199) the Qumranites (only

15.Cf. especially with regard to the mutual sharing Philo's Quod Omnis Probus Liber, 85-86. full members) had their daily meal, blessed by the priest and regarded as sacred (1QS 6:2-3; 1QSa 2:17-21). The function was to express the unity of the community. The historical Jesus also had a similar meal, but one of open table fellowship, especially for crowds who had nothing to eat (Mk 6; Lk 14:15-24; Thomas 64, Crossan 1995:66-70). As early as in 1901, the great Albert Schweitzer (Schweitzer 1901; see critical discussion in Grässer 1979:45-64) indicated that what later became the Eucharist derived from Jesus' eating and drinking with his disciples, as can also clearly be derived from his original remark during the Last Supper (Lk 22:18): ' ... from now on I shall not drink of the fruit of the vine until the kingdom of God comes'. After his death the early Christians 'broke the bread from house to house' (Ac 2:43-47; 4:32-36), in a sense continuing Jesus' practice of open commensality (as was also meant to be the case with the 'love meals' of 1 Cor 11:20-21). When Jesus' death was interpreted by the post-Easter church as a sacrificial death, the Eucharist became a cultic ritual (as in Qumran, but with the bread and wine symbolising Jesus' blood and body). The primary concern to feed the literary poor faded into the background. One cannot but think that if the priority of the historical Jesus had remained the primary concern in Christianity, the bitter doctrinal disputes regarding the Eucharist during the Reformation would have been unnecessary.

\section{Animal sacrifices, Jesus' death, and love and reconciliation}

After the Qumranites withdrew from the temple, no animal sacrifices were made in the community because they regarded themselves as sacrifices to God (Kugler 2000:90-112). According to 1QS 9:3-5, 'atonement will be made for the land more effectively than by the flesh of whole burnt offerings and the fat of sacrifices' (translation by Pfeiffer 1957). Jesus of Nazareth did not forbid sacrifices (Mk 1:44) but deprioritised them (Mk 12:33). Crossan (1994:168) commented on Matthew 5:23-24: 'Gift, altar, and even God must wait for peace and forgiveness. Reconciliation on earth precedes ablation to heaven. ${ }^{16}$ In post-Easter Christianity the sacrificial interpretation of Jesus' death abolished animal sacrifices (Rm 5:6-10; 12:1; Heb 10:1-10). Noteworthy, in the case of the historical Jesus, the abolishment or relativisation of animal sacrifice was linked to love, peace and reconciliation among humans (Mk 12:33).

\section{Prayers long and short}

For the Qumran community, prayer was of the utmost importance. The refectory was not only a dining hall but a prayer room (Schuller 2000:29-45). ${ }^{17}$ The prayers were long and took place at sunrise and sunset (Vermes 1997:78). The hymn scroll $(1 \mathrm{QH})$ contains about 25 thanksgiving hymns of some length. Furthermore there were liturgical prayers, daily prayers and prayers for festivals (e.g. 1Q34, 4Q503 and 4Q507, respectively; cf. Vermes 1998:368-373). Jesus warned

16.This is reminiscent of a remarkable verse from the Tanak, Psalm 85:13: 'Justice will go before him [that is YHWH], and make a way for his footsteps'.

17.It also functioned as an assembly hall, where deliberations took place regarding the general life of the community. 
against long prayers to impress others and presented to his disciples a relatively short prayer. Whereas the Our Father reflects Jesus' message of the kingdom of God and emphasises forgiveness and/or cancelling of debts (cf. Crossan 2010:143162), the Qumranite prayers often focus on the distress and trouble of the supplicant. Jesus also advocated private prayer, as was his own practice when he withdrew into nature (not only the desert but also mountains). Luke's Gospel pictured a Jesus who also advocated longer prayers (cf. the parable of the widow and the judge; Lk 18:1-8), which seems to imply that Jesus also allowed for longer prayers (if the parable was not the creation of the evangelist). In the post-Easter church, Christians were also prompted to pray for all people, especially for the authorities (1 Tim 2:1-2). The latter can be viewed as reflecting an alternative view of that of the earthly Jesus, whose petition for God's rule to be realised actually constituted a subversive criticism of oppressive earthly governments (cf. Lk 22:25).

\section{Scribal activity versus creative teaching and societal engagement}

As already noted, the Qumranites were scribes (Stegemann 1998), who not only copied scrolls but studied them in order to live scrupulously according to the stipulations of Mosaic Law. The pesher commentaries on Habbakuk and Nahum (1QpeshHab and 4Q169 [4QpNah]), where the text is interpreted in terms of their own context, testify to this. The study of scripture was part of their religious services, which included the singing of hymns and prayer (cf. Eph 18:19-20). Throughout the Gospels, Jesus of Nazareth (who most probably was (semi-)illiterate) stood in opposition to the scribes, who, because of their strict observance of the law, took offence at Jesus' free interaction with the scriptures with love and mercy as the ultimate criterion (cf. Mk 10:3-7; Mt $5: 21-47,22: 37-40)$. In the post-Easter church the meticulous study of scripture became more important, as can be seen from Paul's letters, in which he endeavours to motivate his kerygma by referring to the Old Testament (see Scheffler 2011). The Old Testament also played a significant role in Luke's Gospel, although his use of scripture can be typified as 'creative interpretation', reflecting more the practice of the historical Jesus (Scheffler 2013:118-125). According to 2 Timothy 3:16, 'all scripture is regarded as inspired by God' and of great value 'for training in righteousness' - a view that echoes the stance of the Qumran community. It can be concluded that Jesus of Nazareth, in an oral context, lived in free interaction with the scriptural tradition of the Old Testament, but he was not bound by it and never became sedentary to study it. He went into society and could motivate his teaching from the Old Testament if he so wished (Mk 10:3-7), but as his parables show, he could even creatively invent his own teaching.

\section{The kingdom of God: apocalyptic and/or present reality?}

The Qumranites had an apocalyptic expectation of the end of days, in which there would be a cosmic battle with the righteous having the victory (VanderKam 2010:2015-2219). 1QS 3:13-4:26 spells out Qumran's deterministic doctrine of two spirits (of truth and injustice, both created by God!) that dwell in the 'sons of light' and 'sons of darkness', respectively. Finally, after the sons of light have lived according to the precepts of the law, the spirit of truth will win when the two Messiahs (priestly and political) appear and effect atonement (1QSa 9:9-11; Evans 2000). The political Messiah will execute righteous judgement and kill the wicked (CD 14:19). John the Baptist's view about the kingdom of God and the judgement to come compares well with the view of the Qumranites (Mt 3:1-12; Lk 3:1-9). From the days of Weiss ([1892] 1971) and Schweitzer ([1906] 2001:315-354) up to Crossan (1994:149), it has been debated in studies of the historical Jesus whether Jesus had an imminent (cf. Mt 10:23) or realised expectation (kingdom as permanent possibility, Lk 17:20-21) of the kingdom of God. A possibility is that he initially shared the Baptist's view but then began to differ from it, because for him the kingdom was associated with liberation for humankind here and now and not judgement (e.g. Mt 4:1517; 6:10-13; Mt 12:28; Lk 4:42-43; Lk 7:22; 11:20). This accords well with what we have established thus far: the basic attitude of Jesus was love and compassion, and this very fact also predisposed his view of the kingdom of God as a possible present as well as future reality. For the post-Easter church, the focus of kingdom again shifted to a future reality that would arrive at the second coming of Jesus as the Messiah (a title used after Easter, which the historical Jesus in all probability never used for himself, probably because of possible misunderstandings, cf. Casey 2010:392-398). Jesus did not seek titles for himself and constantly referred to himself as the 'Son of man', which need not be interpreted in terms of Daniel 7 but could simply refer to his humanity. Jesus' preaching and ministry focussed on this world without denying an ultimate end, whereas Qumran and the early church focussed their hope on the final salvation (heaven). As soon as such a view is adopted the alleviation of global poverty, sickness and suffering seems to become a side issue. No wonder the 'apocalypticised' Essene community could have a rule excluding physically handicapped people (1QSa 2:48; 4Q266 [CD 15:15]). ${ }^{18}$

\section{Politics, violence and peace}

As we have noted above, the Qumranites withdrew to the desert (avoiding military service) because they were unsatisfied with the Hellenistic sentiments of Alexander Janneus in Jerusalem. Their motive may have been religious (to preserve pious Judaism), but the consequences were intensely political. Their doctrine of the New Covenant entered into by the sons of light (who were themselves) presupposed that 'the sons of darkness' (their enemies) were hated (1QS 1:8-9). The latter would in the end be eradicated in the final cosmic battle under the leadership of the Davidic political Messiah, who would defeat the Wicked Priest (the opponent of the Teacher of Righteousness). This enmity against the sons of darkness (although the battle in 18.Caring for the poor and the sick was restricted to members of the community (CD 14:14-16). 
the interim should be waged by strict adherence to the Mosaic Law) included military fantasies (expressed in the War Scroll [1QM], cf. Maier 2000:40-46), which in the end also meant military conflict and defeat during the Jewish war in 68 CE. ${ }^{19}$

Jesus of Nazareth's teaching of love for the enemy, conquering the latter through good deeds and love (Mt 5:38-48; Lk 6:2736, cf. Scheffler 2016:91-115), which correlates with his teaching on peace-making (Mk 9:49-50; Mt 5:9; 5:23-24; Lk $2: 14,29 ; 7: 50 ; 8: 48 ; 10: 5-6 ; 24: 36)$ is well known. Jesus never advocated violence or war; on the contrary he polemised against it. He was sceptical about power politics (Lk 22:2427). Paul resonated these sentiments (Rom 12, cf. also 1 Pet 3:8-12). The early Christians did not participate in the Jewish war, and unlike the Qumranites they survived it. Interestingly, in the Book of Revelation, where a final cosmic battle is envisaged, we again find apocalyptic thinking similar to that at Qumran (Rev 19:11-21).

Again we conclude that the historical Jesus, ruled by his basic attitude of love and compassion, did not distinguish between the sons of light and the sons of darkness. For him God's sun rose over good and evil, the just and the unjust (Mt 5:45). His politics in this regard are diametrically opposed to those of the Qumranites (cf. Yoder 1972).

\section{Conclusion}

From the above comparison emerges not so much the uniqueness but the radicalness of the message of Jesus of Nazareth. His was a ministry and movement that challenged the institutionalisation of religion. This calls to mind the well-known adage of Alfred Loisy early in the twentieth century that 'Jesus preached the kingdom of God and his followers established the church'. In the same vein, George Bernard Shaw remarked that 'Jesus preached that the kingdom of God is amongst you ... Ever since the church has looked for it somewhere else'. Jesus' message implied involved action for the benefit of the marginalised in society, whereas in Qumran we are confronted with an elitist group religion that was basically directed towards the self, but simultaneously believed that God was thereby honoured and served.

The Qumran community's practices and views differed sharply from those of the historical Jesus but bore more resemblance to post-Easter Christianity (e.g. baptism, ritual meal and Messianic views). A comparison thus reveals the development that took place after the historical Jesus in the establishment of the church. Jesus of Nazareth stands out as a distinctive figure vis-à-vis the Qumran community. However, even as far as the post-Easter church is concerned significant differences can be noted. The movement Jesus elicited, despite its initial itinerancy, developed into the early

19.The War Scroll contains information on the proclamation of the war (10M1), the programme of the 40-year war (1QM2), disposition and weapon of the front programme of the $40-y e a r$ war (1QM 2), disposition and weapon of the front
formations (5), movements of the attacking infantry (6), disposition and formations (5), movements of the attacking infantry (6), disposition and
movements of the cavalry (6), age of soldiers $(6-7)$, addresses and prayers of the movements of the cavalry (6), age of soldiers (6-7), addresses and prayers of the
battle liturgy (10-12), a prayer recited at the moment of victory (13) and the battle against the Kittim (15-19).
Christian communities, which became sedentary, although not exactly like the Qumranites. It is therefore not implausible that as the Baptist movement merged with early Christianity, the Essenes after the Jewish war also merged with the early church in a similar way, even influencing them. No wonder that in recent scholarship the term 'monastery' (a term from Christianity) could be used to typify the Qumranite community. A comparison such as the one here therefore challenges modern Christianities in terms of assessing to what extent their values and existence can still be related to Jesus of Nazareth, whom they venerate and to whom they owe their existence. Can it be that one throw of a stone by Muhammad ed-Dhib, an Arab Bedouin, has had a ripple effect of eliciting a renewed profound insight into the radical message of Jesus of Nazareth, for the benefit of the suffering world of the twenty-first century?

\section{Acknowledgements Competing interests}

The author declares that he has no financial or personal relationships that may have inappropriately influenced him in writing this article.

\section{References}

Albright, W., 1960, The archaeology of Palestine, rev. edn., Pelican, Middlesex.

Allegro, J.M., 1968, Qumran cave 4, I (4Q158-4q186), Discoveries in the Judaean desert of Jordan 5, Clarendon, Oxford.

Allegro, J.M., 1970, The sacred mushroom and the cross: A study of the nature and origins of Christianity within the fertility cults of the ancient near East, Hodder \& Stoughton, London.

Allegro, J.M., 1979, The Dead Sea scrolls and the Christian myth, Redwood Burn, Newton Abbot.

Barret, C.K., 1970, 'The interpretation of the Old Testament in the New', in P.R. Ackroyd \& C.F. Evans (eds.), The Cambridge history of the Bible: Volume 1: From the beginnings to Jerome, pp. 377-411, Cambridge University Press, Cambridge.

Baumbach, G., 1969, s v 'Qumran', BHH.

Bimson, J.J. \& Kane, J.P. (eds.), 1985, New Bible atlas, Inter-Varsity Press, Leicester. Bornkamm, G., [1956] 1975, Jesus von Nazareth, 10. Aufl., Kohlhammer, Stuttgart.

Botha, P.J.J., 2001, 'Judaism in the Graeco-Roman world', in G. van den Heever \& E. Scheffler (eds.), From Jesus Christ to Christianity: Early Christian literature in context, pp. 42-88, Unisa Press, Pretoria.

Bruce, F.F., 1974. s v 'Qumran', in Israel pocket library: Archaeology.

Bultmann, R., 1968, Theologie des Neuen Testaments, 6. Aufl., Mohr, Tübingen.

Burrows, M., 1961. sv 'Qumran', RGG. 3rd edn.

Casey, M., 2010, Jesus of Nazareth: An independent historian's account of his life and teaching, T \& T Clarke, London.

Conzelmann, H., 1978. Geschichte des Urchristentums, Vandenhoeck, Göttingen.

Craffert, P.F., 2008, The life of a Galilean shaman: Jesus of Nazareth in anthropologicalhistorical perspective, Cascade books, Eugene, OR.

Crossan, J.D., 1991, The historical Jesus: The life of a Mediterranean Jewish Peasant, T \& T Clarke, Edinburgh.

Crossan, J.D., 1994, The essential Jesus: Original sayings and earliest images, HarperSanFrancisco, New York.

Crossan, J.D., 1995, Jesus: A revolutionary biography, HarperSanFrancisco, New York.

Crossan, J.D., 2010, The greatest prayer: Rediscovering the revolutionary message of the Lord's prayer, HarperSanFransisco, New York.

Crossan, J.D. \& Reed, J.L., 2001, Excavating Jesus: Beneath the stones, behind the texts, HarperSanFrancisco, New York.

Davies, P., 1989, 'Beyond the Old Testament', in J. Rogerson \& P. Davies (eds.), The Old Testament world, Canbridge University Press, Cambridge.

Davies, S.L., 1995, Jesus the healer: Possession, trance and the origins of Christianity, SCM, London. De Vaux, R., 1973, Archaeology and the Dead Sea scrolls, Oxford University Press,
London.

De Vaux, R. \& Broshi, M., 1993, 'Qumran, Khirbet and 'Ein Feshka', The New Encyclopedia of Archaeological Excavations in the Holy Land 4, 1235-1241. 
Dreyer, Y., 1999, 'Jesus en vroue', HTS Theological Studies 55(1), 70-96. http://dx.doi. org/10.4102/hts.v55i1.1523

Dupont-Sommer, A., 1952, The Dead Sea scrolls: A preliminary survey, Blackwell, Oxford.

Du Rand, J.A., 1998, 'Groups in Jewish national life in the New Testament period', in A.B. du Toit (ed.), The New Testament Milieu, Orion, Halfway House.

Ehrman, B., 2012, Did Jesus exist? The historical argument for Jesus of Nazareth, HaperCollins Publishers, New York.

Eshel, H., 2009, Qumran: Scrolls, caves, history, Carta, Jerusalem.

Evans, C.A., 2000, 'Qumran's Messiah: How important is he?', in J.J. Collins \& R.A Kugler (eds.), Religion in the Dead Sea scrolls, pp. 135-149, Eerdmans, Grand Rapids, MI.

Farrington, K., 2003, Historical atlas of the holy lands, Thalamus, New York.

Fensham, C., 1976, Die Dooie See rolle en die Bybel, Tafelberg, Kaapstad.

Flint, P., 2006, 'Jesus and the Dead Sea scrolls', in A.-J. Levin, D.C. Allison \& J.D. Crossan (eds.), Religion in the Dead Sea scrolls, pp. 110-131, Eerdmans, Grand Rapids, MI. Flint, P., 2013, The Dead Sea scrolls, Abingdon Press, Nashville.

Flint, P., 2014, 'The Qumran scrolls and the historical Jesus', in J.H. Charlesworth \& B. Rhea (eds.), Jesus research: New methodologies and perceptions, pp. 261-282, Eerdmans, Grand Rapids, MI.

Gal, Z., 2010, Qumran: Scrolls in the desert, Ostracon, Bar-Lev.

Golb, N., 1995, Who wrote the Dead Sea scrolls?: The search for the secret of Qumran Scribner, New York.

Grässer, E., 1979, Albert Schweitzer als Theologe, Mohr, Tübingen.

Gunneweg, A.H.J., 1972, Geschichte Israel's bis Bar Kochba, Kohlhammer, Stuttgart.

Horsley, R.A., 2006, 'The Dead Sea scrolls and the historical Jesus', in J.H Charlesworth (ed.), The Bible and the Dead Sea scrolls: Volume three: The scrolls and Christian origins, pp. 37-60, Baylor University Press, Waco, TX.

Harrington, H.K., 2000, 'The Halakah and religion of Qumran', in J.J. Collins \& R.A. Kugler (eds.), Religion in the Dead Sea scrolls, pp. 74-89, Eerdmans, Grand Rapids, MI.

Hengel, M., 1988, Judentum und Hellenismus: Studien zu ihrer Begegnung unter besonderer Berücksichtigung Palästinas bis zur Mitte des 2.Jh.s v. Chr., 3. Aufl., Mohr, Tübingen.

Hermann, S., 1980, Geschichte Israels in altestamentlicher Zeit, Kaiser, München.

Jagersma, H., 1985, Geschiedenis van Israel van Alexander de Grote tot Bar Kochba, Kok, Kampen.

Kazantzakis, N., [1953] 1960, The last temptation of Christ, Simon \& Schuster, New York. Keller, W., 1981, Und die Bibel hat doch recht, Rowohlt, Düsseldorf.

Kravitz, N., 1973, 3,000 years of Hebrew literature, W.H. Allan, London.

Kugler, R.A., 2000, 'Rewriting rubrics: Sacrifice and the religion of Qumran', in J.J. Collins \& R.A. Kugler (eds.), Religion in the Dead Sea scrolls, pp. 90-112, Eerdmans, Grand Rapids, MI.

Kuhn, K.G. sv 'Qumran', in RGG. 3rd edn.

Lohse, E., 1971., Die Texte aus Qumran: Hebräisch und Deutsch, Kösel-Verlag, München.

Maier, J., 1972, Geschichte der jüdische religion, Kohlhammer, Stuttgart.

Maier, J., 2000, Kriegsrecht und Friedensordnung in jüdischer Tradition, Kohlhammer Stuttgart.

Martínez, F. \& Tigchelaar, E., 1999. The Dead Sea Scrolls study edition, Brill, Leiden.

Meeks, W., 1986, The moral world of the first Christians, Westminster, Philadelphia, PA.

Metzger, M., 1983, Grundriss der Geschichte Israels, 6. Aufl., Neukirchener Verlag, Neukirchen.

Millard, A., 1990, Discoveries from the time of Jesus, Lion Publishing, Oxford.

Murphy-O'Connor, J., 2008, The Holy land: An Oxford archaeological guide from earliest times to 1700, 5th edn., Oxford University Press, Oxford.

Noth, M., 1960, The history of Israel, Harper \& Row, New York.

Oesterley, W.O.E., 1932, A history of Israel: Vol. II: From the fall of Jerusalem, 586 B.C. to the Bar-Kokhba revolt, A.D. 135., Clarendon Press, Oxford.

Pfeiffer, C.F., 1957, The dead sea scrolls, Baker Book House, Grand Rapids, MI.
Reicke, B., 1957, Leben und Glauben in der Urgemeinde: Bemerkungen zu Apg.1-7, Zwingli-Verlag, Zürich.

Reicke, B., 1968, Neutestamentlich Zeitgeschichte: Die biblische Welt 500v. - $100 \mathrm{n}$. Chr. 2. Aufl., De Gruyter, Berlin.

Ringgren, H., 1963, Israelitischer religion, Kohlhammer, Stuttgart.

Scheepers, C. \& Scheffler, E., 2000, From Dan to Beersheba: An archaeological tour through ancient Israel, Biblia Publishers, Pretoria.

Scheffler, E., 1993, Suffering in Luke's Gospel, Theologischer Verlag, Zürich.

Scheffler, E., 2000, 'Qumran - Home of the Dead Sea scrolls', in C. Scheepers \& E. Scheffler (eds.), From Dan to Beersheba: An archaeological tour through ancient Israel, pp. 176-213, Biblia Publishers, Pretoria.

Scheffler, E., 2011, 'Paul's (mis)use of the Old Testament in the letter to the Romans', Scriptura 108, 269-289.

Scheffler, E., 2013, 'The assaulted (man) on the Jerusalem-Jericho road: Luke's creative interpretation of 2 Chronicles 28:15', HTS Theological Studies 69(1), 118 125. http://dx.doi.org/10.4102/hts.v69i1.2010

Scheffler, E., 2016, 'The historical Jesus and (non)violence: A contemporary challenge', in J. Hunter \& J. Kügler (eds.), The Bible and violence in Africa, pp. 91-115, University of Bamberg Press, Bamberg.

Schnackenburg, R., 1973, 'Das Urchristentum', in J. Meier \& J. Schreiner (eds.) Literatur und Religion des Frühjudentums, Echter Verlag, Wurzburg.

Schonfield, H., 1984, The Essene odyssey: The mystery of the true teacher \& the Essene impact on the shaping of human destiny, Element, Schaftbury.

Schottroff, L. \& Stegemann, W., 1978, Jesus von Nazareth: Hoffnung der Armen Kohlhammer, Stuttgart.

Schuller, E., 2000, 'Petitionary prayer and the religion of Qumran', in J.J. Collins \& R.A Kugler (eds.), Religion in the Dead Sea scrolls, pp. 29-45, Eerdmans, Grand Rapids, MI.

Schweitzer, A., 1901, Das Abendmahl im Zusammenhang mit dem Leben Jesu und der Geschichte des Urchristentums. Erstes Heft. Das Abendmahlsproblem auf grund
der wissenschaftlichen Forschung des 19. Jahrhunderts und der historischen der wissenschaftlichen Fors
Berichte, Mohr, Tübingen.

Schweitzer, A., [1906] 2001, The quest for the historical Jesus, Fortress Press, Minneapolis, MN

Stauffer, E., 1959, Die Botschaft Jesu: Damals und Heute, Francke Verlag, Bern.

Stegemann, H., 1998, The library of Qumran, Eerdmans, Grand Rapids, MI.

Strauss, D.F., [1835] 1972, The life of Jesus critically examined, Fortress, Philadelphia, PA.

Tenney, M.C., 1967, New Testament times, Intervarsity-Press, London.

Theissen, G., 2004, Die Jesusbewegung: Sozialgeschichte einer Revolution der Werte, Gütersloher Verlagshaus, Gütersloh.

Theissen, G. \& Merz, A., 2011, Der historische Jesus: Ein Lehrbuch. 4. Aufl., Vandenhoeck, Göttingen.

Thiering, B., 1992, Jesus the man, Corgi Books, London.

Thompson, J.A., 1989, The Bible and archaeology, 3rd edn., Eerdmans, Grand Rapids, MI.

VanderKam, J.C., 2000, 'Apocalyptic tradition in the Dead Sea scrolls and the religion of Qumran', in J.J. Collins \& R.A. Kugler (eds.), Religion in the Dead Sea scrolls, pp. 113-134, Eerdmans, Grand Rapids, Ml.

VanderKam, J.C., 2010, The Dead Sea Scrolls Today, 2nd edn., Eerdmans, Grand Rapids, MI.

Van der Ploeg, J., 1957, Vondsten in de woestijn van Juda: De rollen der Dode See, Het Spectrum, Utrecht.

Vermes, G., 1977, The Dead Sea scrolls: Qumran in perspective, Collins, London.

Vermes, G., 1998, The complete Dead Sea scrolls in English, Penguin, London.

Vriezen, Th.C. \& Van der Woude, A.S., 1973, Literatuur van Oud-Israël, Sevire, Wassenaar.

Weiss, J., [1892] 1971, Jesus proclamation of the kingdom of God, Fortress, Philadelphia, PA.

Wright, G.E., 1962, Biblical Archaeology, Duckworth, London.

Wright, N.T., 1996, Jesus and the victory of God, Fortress Press, Minneapolis, MN.

Yadin, Y., 1973, Masada: Herod's fortress and the Zealot's last stand, Cardinal, London. Yoder, J.H., 1972, The politics of Jesus: Vicit Agnus Noster, Eeerdmans, Grand Rapids, MI. 